\title{
沖縄本島・旧勝連間切の近・現代における村落空間の特徵と変遷 - 村落空間構成の復元を通じて その $2-$ \\ A STUDY ON THE FEATURES AND TRANSFORMATIONS OF SPATIAL COMPOSITION IN RURAL VILLAGES OF OLD KATSUREN MAGIRI, MAIN ISLAND OF OKINAWA \\ - Using the restored old maps for analysis on spatial composition Part 2-
}

\author{
鎌田誠史*, 山元貴 継**, 浦山隆一 ***, 渋谷鎮 明**** \\ Seishi KAMATA, Takatsugu YAMAMOTO, Takakazu URAYAMA \\ and Shizuaki SHIBUYA
}

\begin{abstract}
The purpose of this study is to reproduce the restored old maps of rural villages on the main island of Okinawa by cadastral maps made in 1902-1903, in combination with historical records. Moreover, changes of the spatial composition of each village were analyzed by comparing their restored maps with the aerial photographs by the U.S. Forces, the present maps and field survey. It was found that the general structure of streets described as "grid-pattern", and the location of holy places called Utaki had seldom changed until present. On the other hand, residential area had greatly expanded in each village, and a large areas of the farmlands and woods had now vanished in comparison with the restored maps.
\end{abstract}

Keywords: Main Island of Okinawa, Katsuren Magiri, Rural villages, Spatial composition, Restored maps 沖縄本島, 勝連間切, 村落, 空間構成, 復元図

\section{1.はじめに}

本研究は、沖縄本島・旧勝連間切（現うるま市勝連町）の南風原 村、平安名村、内間村、平敷屋村注1）を対象として、明治期の資料 などから村落空間の復元図を作成し、明治 $35 \cdot 36$ 年当時の村落空 間の特徴注 2）を示すとともに、現在に至る空間的変遷を明らかにす ることを目的とする。

前稿 ${ }^{1)}$ では、沖縄県石垣島の近・現代における村落空間の特徴と 変遷を考察した。そこでは、石垣市の対象村落において、村落外縁 部には帯状で幅の細長い形状の、村抱護注3) と呼ばれる樹林帯が分 布し、加えてこのような村抱護と聖域（御岦）が結合しながら居住 域とその周りの生産域を抱き囲むように分布するという、共通した 特徵を指摘した。明治期から現在の村落空間については、共通して 明治期の空間構成が昭和 20 年頃まで維持され、戦後から近年の都 市化によって居住域が拡大し、生産域が減少または消滅する事によ る村落構成の変化が見られた。一方で、聖域はほぼ変化していない ことが明らかとなった。

本稿では、このような形態上の特徴と変遷の考察を前提として、 沖縄本島の村落に注目する。まずは既存の文献や伝承をあらかじめ
確認した上で、明治 $35 \cdot 36$ 年作成の地籍図（以下、明治期地籍図） を用いて村落空間の復元図注4) を作成し、空間的な特徵を述べる。 次に、作成した明治期の復元図を、昭和 20 年頃の米軍撮影空中写 真注 5)、昭和 $42 \sim 57$ 年作成の「一筆地調査図」注 6)、現在の地籍併 合図、住宅地図と比較し、加えて現地確認を行うことで、明治期か ら現在に至る村落空間の変遷を明らかにする。なお、沖縄では去る

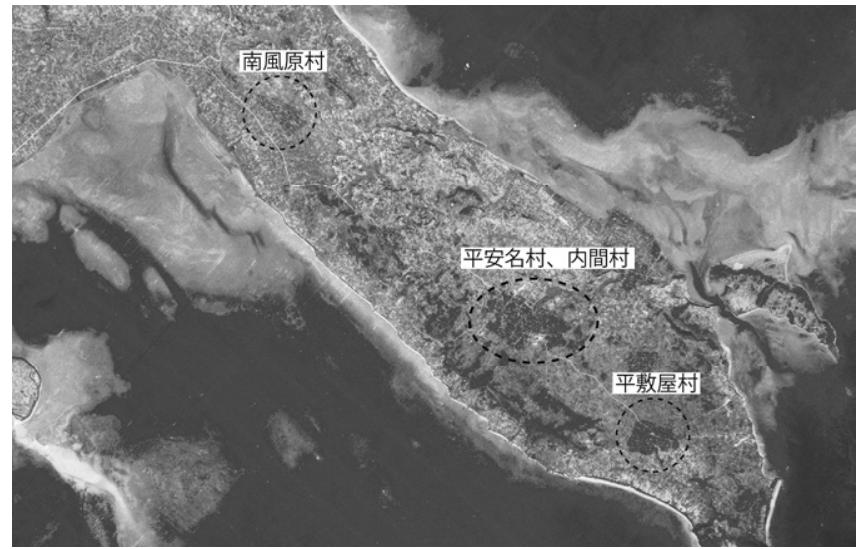

図 1 米軍撮影空中写真（昭和 20 年頃）沖縄県立公文書館蔵
有明工業高等専門学校建築学科

准教授・博士 (芸術工学)

** 中部大学人文学部 准教授. 博士 (地理学)

*** 富山国際大学現代社会学部 教授・博士 (芸術工学)

**** 中部大学国際関係学部 教授. 博士 (地理学)
Assoc. Prof., Dept. of Architecture, Ariake National College of Technology, Ph. D.

Assoc. Prof., College of Humanities, Chubu Univ., Ph. D.

Prof., Dept. of Contemporary Sociology, Toyama Univ. of International Studies, Ph. D.

Prof., College of International Studies, Chubu Univ., Ph. D. 
大戦で復元の根拠となる史料の多くが焼失したとされる経緯注 7) が あり、明治期地籍図を用いた村落空間の復元図の作成による分析は 普遍的には行われていない注8)。本稿で対象とした土地整理事業当 時の地籍図は、沖縄本島においては現在今帰仁村、南城市（旧大里 村)、うるま市 (旧勝連町) で確認されているのみであるが、その地 籍図を活用寸ることで、今まで明らかにされていなかった明治期に おける村落の特徵を可視的に示すことが可能となる。

\section{2、明治期地籍図の特徴}

沖縄本島では残念ながら、前稿で取り上げた「八重山古地図（明 治 20 年から 30 年作図)」に相応寸る絵図は現時点で確認されてい ない。明治期における沖縄本島の村落の具体的な空間構成を知る有 効な資料は明治期地籍図となる。ただし沖縄本島では、明治期地籍
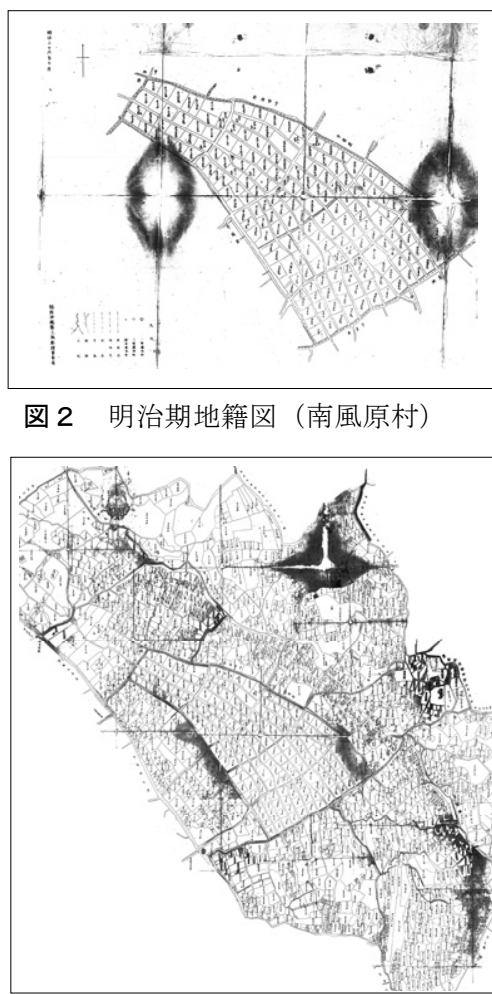

図 3 明治期地籍図

（つなぎ合わせ加工）（南風原村）
図 2 明治期地籍図（南風原村）

図においても字全図が残存 している地域は極めて少な (2)。

その中で、今回入手した 勝連間切の明治期地籍図は、 うるま市勝連字南風原が所 有する明治 $20 \sim 30$ 年に作 成された地割関係の文書 「勝連間切南風原文書（沖 縄県指定有形文化財)」に納 められた「中頭郡勝連間切 南風原村地押見取図」で、 第壱号の字南風原から第式 拾七号の字勢理客までで、 計 29 葉からなる地籍図 集である。勝連間切の明 治期地籍図は、前稿で分 析した石垣市一帯の明治 期地籍図と同様に縮尺が $1 / 1,200$ で、道路や地割 形状が正確に表現され、 各地筆には地番と地目

(宅地、田、畑、拝所、 雑種地、池沼、溜池、山林、原野の 9 種類）が記載されている。 また、石垣市一帯の地籍図と同様に、山林や原野に「保安林注9)」 と記された箇所がある。

\section{3. 明治期（35・36 年）当時の村落の特徵}

明治期地籍図を使用し、前稿と同様の方法注 10 ) で対象村落に ついて復元図を作成した。そして、作成した復元図をもとに、建 築学的立場からの空間把握のために、「点・線・面」の複合体とし て村落空間を分析する。このように空間を「点」「線」「面」に分 け、それぞれがどのような秩序をもって関係し、空間を構成して いるかという視座に立って分析することは、村落の物的な秩序を 捉えて理解する上で有効な方法であると言える ${ }^{3)}$ 。

本稿では、明治期地籍図や文献・伝承から確認できた要素につ いて、点的要素としては村番所、ノ口殿内、根屋、クムイ（村池）
村獅子、殿、拝所、学校、井戸 (カー)、アシビナー、馬場、墓と、 一部の山林、原野を取り上げる。線的要素としては、主に村落の骨 格を構成する「道」と、加えて水路等を取り上げる。面的要素は、 生産域、居住域、聖域、山林とする。

\section{（1）南風原村（図 4）}

当村落は、沖縄本島中部東海岸、勝連半島の付根部分に位置し、 西南側は中城湾に面する (図 1 )。北東側の丘陵地から西南向きに広 がる村落である。

\section{1 ）明治期地籍図にみる村落の特徵}

村落の点的要素としては、居住域を中心に、溜池 (池沼)、雑種地、 畑、山林、原野が数ヶ所に分布している。また、村落北西側には墓 が分布している。

線的要素をみると、居住域の東西端の道路 2 本および村落内を南 北方向に縦断する道路 4 本があり、これらによって後述する居住域

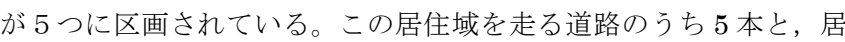
住域から少し離れた場所を斜めに走る道路につながる道路とが連結 している。

面的要素としては、生産域に囲まれるように居住域が分布してい る。生産域は畑が多くを占めているが、田も若干分布している。居 住域の北東側には、山林と原野が居住域、生産域を取り囲むように 分布している。なお地籍図上、村落内には拝所は分布していない。 居住域内の道の両側もしくは片側には、水路が見られる。居住域の 地割形態は井然型（ゴバン型）で、各街区は $1 \times 4 \sim 5$ 筆の横一列 型の地筆で構成されている。ただし、居住域南東側から $1 \sim 3$ 区画 は $1 \times 2 \sim 5$ 筆注 1 1) で構成されているのに対して、南東端から 4 ～ 5 区画は $1 \times 3 \sim 7$ 筆の横一列型と田の字型で構成されている。

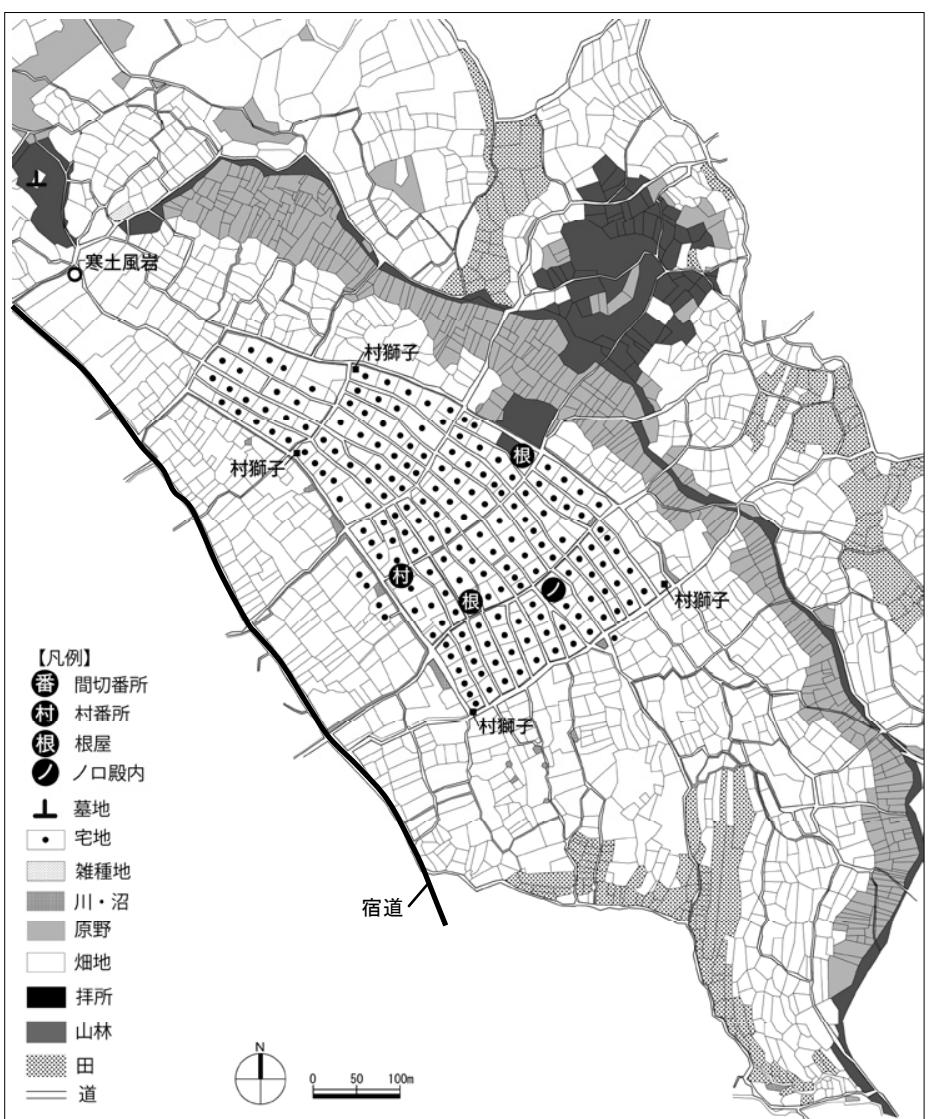

図 4 復元図（南風原村） 
後述するように、後者の区画は比較的新しいものである。特に南東 端から 5 区画目は、他と比較して直線的な道路構成となっている。 生産域の地割形態について、短冊状の畑地は極めて少なかった。

\section{2 ) 文献・伝承等にみる村落の特徵}

村落はもともと勝連グスクの南方、元島原と呼ばれた中城湾に面 寸る傾斜地にあったが、 1726 年頃に北方の現在地に移ったとされる 注 12 2)。絵図郷村帳に「はへ原村」、琉球国高究帳に「南風原村」と 見え、1879（明治 12）年頃までに浜崎村を合併したとされる。ま た 1856 年には住民が南風原村の乾田に灌溉用水を引き、そこに水 田を開発して褒賞された（『球陽』）との記録がある4 ${ }^{4}$ 。

村落の点的要素としては、居住域の宅地に村番所、ノ口殿内、根 屋が分布している ${ }^{5)}$ 。また居住域の四隅には村獅子(現指定文化財) が置かれ、これは「南風原の村獅子」と称される村のフーチゲーシ(邪 気払い)として、元島原より移動した 1726 年頃に、村の境界として 東西南北の四隅に置かれたと伝えられている5)。村落移動当時は、 南東側から 4 つの区画についてのみ居住域が展開していたとされ, 村獅子もこの範囲の四隅に置かれてきた。そこに、現在までにさら に西北側にもう 1 区画が追加され，居住域が拡大したとされる ${ }^{5)}$ これを象徴するかのように, 現在の住民も南東側の区画から 1 班〜 4 班，そして 5 班といったように村落内を区分して呼んでいる。

線的要素として、居住域から少し離れた場所を斜めに走る道路は、 かつての宿道注 13$)$ とされる。居住域内の水路は、1856 年に設けら れた灌溉用水路に関係しているとされる5)。

面的要素としては、居住域の北側にある山林と原野の範囲が村落 の腰当森の機能を果たしているとされ、地元では「黄金森（クガニ ムイ)」と呼ばれる。伝承によると、黄金森は母親が背後から子供を 抱いた姿に似ており、元島原からの村落移動の際には、この黄金森
村落が囲まれる構造は、前稿で指摘した八重山・石垣島の空間的特 徵である「村抱護」に極めて類似している。これらの村落には風水 思想に基づいた地理的な概念、いわゆる「抱護」に基づく山林が存 在した可能性が考えられる。このように、八重山・石垣島の村落空 間とは共通性があると言える。また、この山林および寒土風岩の外 側に墓が分布していることから、山林に囲まれた範囲が「村域」で あったと考えられる。これも前稿で取り上げた、村抱護の外側に墓 が分布する村落（平得・真栄里村、大濱村、宮良村）の構成と共通 している。

以上より、南風原村の特徵として、居住域の井然型の地割形態や 水路、村池の整備に加えて村落移動（村建て）の際の基点が存在し たことと、腰当森の山林が帯状に村落を取り囲む村抱護が明らかに 見られることは、往時における近世村落の村落計画が表象された結 果ではないかと思われる。

\section{(2) 平安名村 (図 5)}

当村落は、沖縄本島中部東海岸、勝連半島の中央部分に位置し、 南は中城湾に面する (図 1 )。南側の丘陵地から北東向きに広がる村 落である。北側はなだらかな勾配で下がっており、一部居住域内に 小高い丘が存在する。同村落は、隣接する内間村と一村のような様 相を呈している。

\section{1 ）明治期地籍図にみる村落の特徵}

村落の点的要素としては、居住域を中心に扯所、溜池、雑種地、 畑、山林、原野が数力所分布している。また、村落西端部には墓が 分布している。

線的要素としては、村内には南風原村と同様に水路が設けられて いるが、居住域を取り囲む帯状の山林は見られない。

面的要素としては、生産域に囲まれるように居住域が展開してい
に加えて、寒土風岩（ナラカジラーイシ）と呼 ばれる大岩を右手、フェーノアギ原石を左手と し、これら 3 点を軸に、現在の村落を計画した とされる ${ }^{5)}$ 。

\section{3) 村落の特徵の分析}

村落内には御获は存在せず、御訔、殿、ノロ 火神はすべて、南側に隣接する勝連グスク内に 分布している。また、村落北西部に寒土風岩 (ナ ナカジラーイシ) と呼ばれる高さ $5 \mathrm{~m}$ 、周囲 $10 \mathrm{~m}$ の石灰岩の大岩が実在している。村落内に聖域 の御嶽がない理由としては、村落が勝連グスク に近接しており、容易に行き来できるため、新 たに必要とされなかったことが考えられる。

居住域の北東側は丘陵地で、ここの帯状の山 林地筆が村落全体を取り囲む形となっており、 のちにこれらの山林地筆は保安林指定までを受 けている点が注目される。腰当森に分布する帯 状の山林（後に保安林と加筆）が村落を取り囲 み、先述した寒土風岩がちょうどその山林の右 手の先端に位置しており、伝承は復元図でも確 認することができる（図 4)。なお、フェーノア ギ原岩の場所は不明であるが、山林の左手先端 にあったと想定される。こうした山林によって

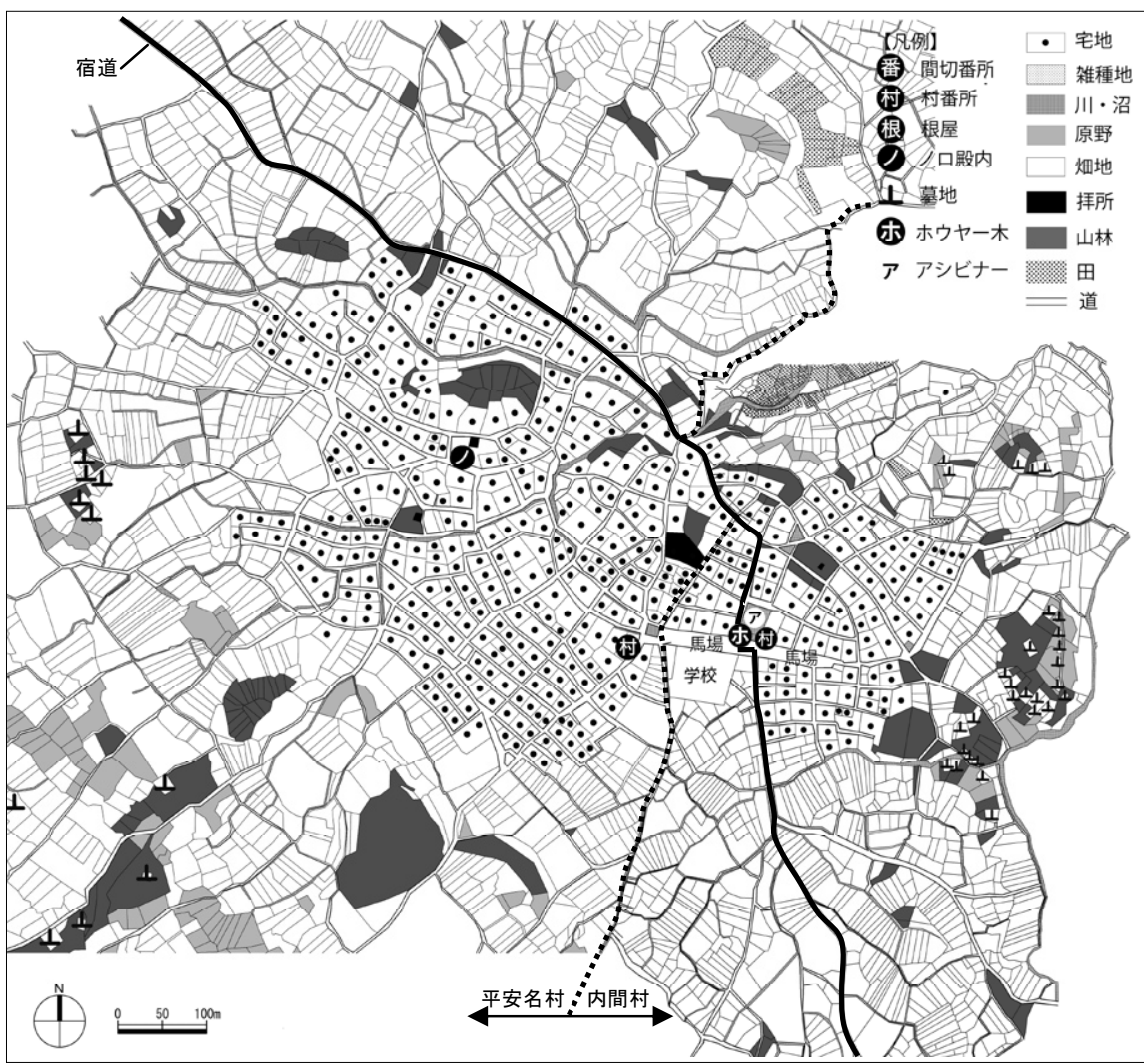

図 5 復元図 (平安名村、内間村) 
る。この居住域の地割形態においては、井然型（ゴバン型）と不井 然型とが並存している。居住域の中央部分は不井然型であるが、南 北端には井然型の地割が分布している。中央部分の街区の構成は田 の字型で、筆数もまちまちであるのに対して、端部の構成は $1 \times 3$ ～ 5 筆の横一列型が多く、縦一列型も見られる。生産域の地割形態 としては、短冊状の畑地が多数を占めている。

\section{2 ）文献・伝承等にみる村落の特徵}

絵図郷村帳、琉球国高究帳に「平安名村」と見え、村落移動の記 述は見られない4)。

点的要素としては、居住域を中心に村屋、アシビナー（遊び庭）、 村池、ノロ殿内、シキン御嶽、ウーブ（オウブノ）猚、拝所が分布 している4) 5)。

線的要素としては、居住域北側に接した道がかつての宿道とされ る。

\section{3) 村落の特徵の分析}

当村は近世期においても移動のない村落（不移動型）である。居 住域の中央部分に村の主な施設が分布しており、この中央部分の地 割形態は不井然型である。そして、この部分から村が発達して居住 域が拡大するにつれ、端部に井然型の地割が形成されたと考えられ る。また、居住域の中央部分には小高い丘があり、特にその周辺は、 起伏に富んだ地形のために不井然型となったとも考えられる。宿道 は居住域内を通り、隣接する内間村も横断している。なお、宿道が 平安名村と内間村の村境を通らず内間村内を横断している点も特徵 となる。

居住域の周辺は丘陵地で墓が分布している。その内側が生産域、 居住域、聖域の大きく3つの要素から構成されている。

(3) 内間村 (図 5)

\section{1) 明治期地籍図にみる村落の特徵}

村落の点的要素としては、居住域を中心に拝所、溜池（池 沼)、畑、山林が数力所分布している。また、村落東端部に は墓が分布している。

線的要素としては、村内に南風原村と同様に水路が設け られているが、居住域を取り囲む帯状の山林は見られない。 面的要素については、平安名村と同様の配置構成となる。 ただし、居住域の地割形態はほぼ全域が井然型で、平安名 村に比べて道路がやや直線的である。街区は横一列型、縦 一列型、田の字型が混在しており、それを構成している筆 数もまちまちである。生産域は、短冊状の地割形態となっ ている畑作地が多数を占めている。

\section{2 ) 文献・伝承等にみる村落の特徵}

かつて勝連グスクの東側の前川原にあった村落が、当初 は現在の南風原村の地に移動を計画していたものの、元島 原からの村落が先に南風原村に移動したため、現在の場所 に移動注 14)したとされる ${ }^{6}$ 。

村落の点的要素としては、居住域に古島から移動したと きに植えたとされる内間ホウヤー木（町指定文化財） ${ }^{7)}$ 、 馬場、アシビナー、村池、拝所、学校、井戸などが分布し ている4）5）。仲吉門中の御嶽があったとされる場所の地目 は山林となっている。また、クシミ御猋がクシミ原にあっ たとされるが、場所は不明である。
線的要素としては、宿道が居住域内を横断しており、村屋、内間 ホウヤー木、馬場を横切って村外へとつながっている。

\section{3）村落の特徵の分析}

当村は近世期において移動した村落で、居住域の広い範囲の地割 形態が井然型で、かつ横一列型の街区構成が多数を占める近世村落 の特徴を有している。ただし、丘陵部分では田の字型の街区が分布 していることから、土地の条件に対応して地割の形態を変えている 可能性がある。墓の分布を見ても居住域との距離が近く、かつ東側 の丘陵地に分布していることからも、当村が平安名村に付随する形 で成立したことがうかがえる。なお、宿道が村内の居住域や馬場を 分断している例はきわめてめずらしく、平安名村との村境を境に宿 道がずれている点は注目される。

\section{(4) 平敷屋村（図6)}

当村落は、勝連半島の東南端に位置し、琉球石灰岩の段丘・丘陵 地上に立地しており、平地に乏しい。北は与那城間切、南東部は中 城湾に面する (図 1 )。

\section{1 ）明治期地籍図にみる村落の特徵}

村落の点的要素としては、居住域を中心に拝所、溜池、畑、山林 が数力所分布している。村落西端部には墓が分布している。

面的要素としては、東西に連なる山林を背に居住域、聖域（御嶽 等）が分布し、その北方に生産域が広がっている。また、山林の南 方にも生産域が広がっている。居住域南側の帯状の山林は、南風原 村などとは異なり、後に保安林と加筆されていない。一方で海岸沿 いには、後に保安林と加筆された帯状の山林が分布している。拝所 は居住域、山林、生産域に分布している。居住域の地割形態は不井 然型と井然型が併存している。居住域中央部分は不井然型で、それ らの街区の構成は田の字型、横二列型であるのに対して、居住域の 南北端部では井然型で $1 \times 3 \sim 5$ 筆の横一列型の構成が見られる。

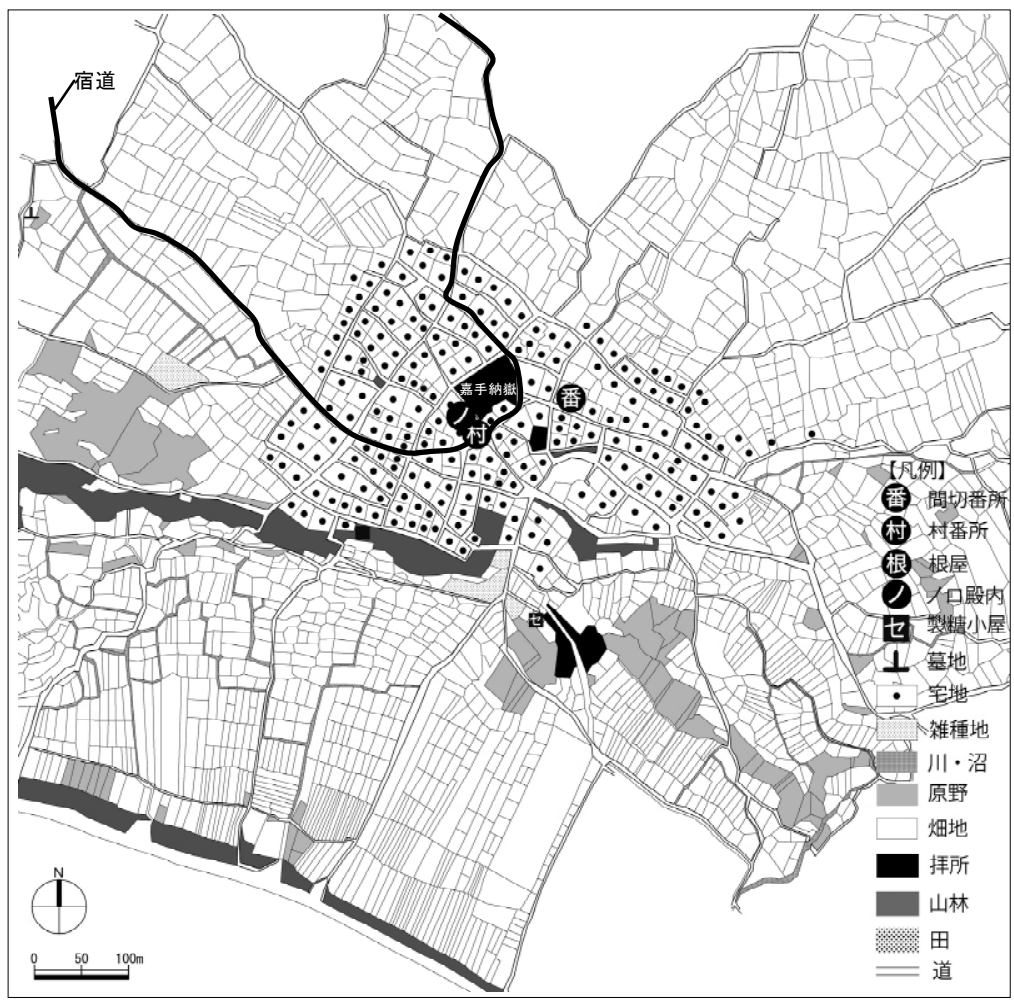

図 6 復元図 (平敷屋村) 
生産域は、特に海岸側において短冊状の地割形態を持った畑が多数 を占めていた。

\section{2 ）文献・伝承等にみる村落の特徵}

かつて「村の高さや平敷屋村」と詠われた ${ }^{8)}$ ように、一帯では丘 陵が西南側を頂点として東側に連峰形に伸びる。村落は、この丘陵 地から北向きに広がっている。また、勝連間切番所の所在地でもあ った（『琉球国旧記』）。

村落の点的要素としては、居住域に間切番所、村番所（根屋との 説あり)、ノ口殿内、择所、嘉手納嶽（シリー御訔）、とうの御嶽な どが分布している。1991 年に平敷屋古島遺跡発掘調查が行われ、嘉 手納㠃（シリー御訔）周辺には、貝塚時代から村落が形成されてい たことが明らかになった。また、平敷屋朝敏（1700～1734）が脇地 頭時代に水不足解消のため池を掘り、その土を盛って丘を築いたと される平敷屋タキノーがある。居住域南側の丘陵地には前又御嶽や 井戸が分布し、さらにその南東側には製糖小屋と拝所、ノロガー（井 戸）が分布している8

線的要素をみると、内間村から延びる宿道が居住域内の間切番所 をつなぎ、北向きに折り返して与那城間切の屋慶名番所へと向かっ ている。

\section{3 ) 村落の特徵の分析}

当村は近世期においても移動のない村落（不移動型）である。居 住域の中央部分には村の主要な施設が分布し、その周囲の地割形態 は不井然型である一方で、居住域の端部は井然型となっていること などは、同じく不移動型である平安名村の構造に類似している。

また、居住域南側の丘陵地の山林は、御訔が置かれ、村の腰当森 として機能している。居住域は嘉手納信（シリー御訔）を中心に北 側に発達したと考えられる。南風原村などで一般的に見られる、北 側の腰当森を背に村落が南方に形成される構造とは異なり、やや特 殊な村落構造であるといえる。海岸沿いには帯状の山林が分布して おり、これは浜抱護（現在の防潮林に相当）とも呼ばれた。なお、 宿道が居住域内の間切番所をつなぎ、北向きに折り返して与那城間
切の屋慶名番所へと向かっている（図 6 ）のは、当村が関連半島の 東南端に位置しているためである。

\section{4. 村落空間の変遷}

明治期の復元図（以下、復元図）を、昭和 20 年頃の様子をとら えた米軍撮影空中写真のほか、土地の境界や地目、所有者を再測量・ 確認し、現在の地籍図の基礎となった昭和 $42 \sim 57$ 年作成注 1 5) の「一 筆地調查図」そして現在の地籍併合図、さらに住宅地図と比較する ことで、明治期から現在に至る村落空間の変遷を明らかにしたい。

\section{（1）昭和 20 年頃（表 1)}

米軍撮影空中写真によれば、南風原村については、居住域、生産 域、道路線形も変化が見られず、宿道沿いの 2 筆の畑地が宅地に変 化しているのみである。また、復元図で示した居住域背後の丘陵地 に分布する帯状の山林の地筆形状にも変化がないことが確認できる。 また、井然型の地割形態となっている居住域においては、分筆など 大きな変化は少ない。

平安名村、内間村も、居住域、生産域、道路形態、地割形態、丘 陵地の山林については、南風原村と同様に変化が少ない。ただし、 居住域端部の畑地において、平安名村では 30 筆程度注 16)、内間村 では 20 筆程度注 16$)$ が宅地に変化しており、その際に畑地の合筆が 見られる。また、内間村では、学校用地が拡大した分の畑地が減少 している。なお、馬場に大きな変化は見られない。

平敷屋村の居住域、生産域、道路線形、地割形態、丘陵地の山林 についても、明治期から大きな变化は見られない。なお、当村では 畑地の宅地化も見られない。

\section{（2）昭和 42 57 年頃（表 1 )}

南風原村の一筆地調查図は昭和 42 年作成である。点的要素であ る村番所、ノ口殿内は個人所有の宅地に変化している。村池は一部 宅地となっているがほぼ残存している。村域内の畑地 43 筆が宅地 に変化している一方で、居住域内の宅地 7 筆が畑地に変化している。 なお、この時期の村獅子の有無については不明である。

表 1 村落空間の変遷まとめ

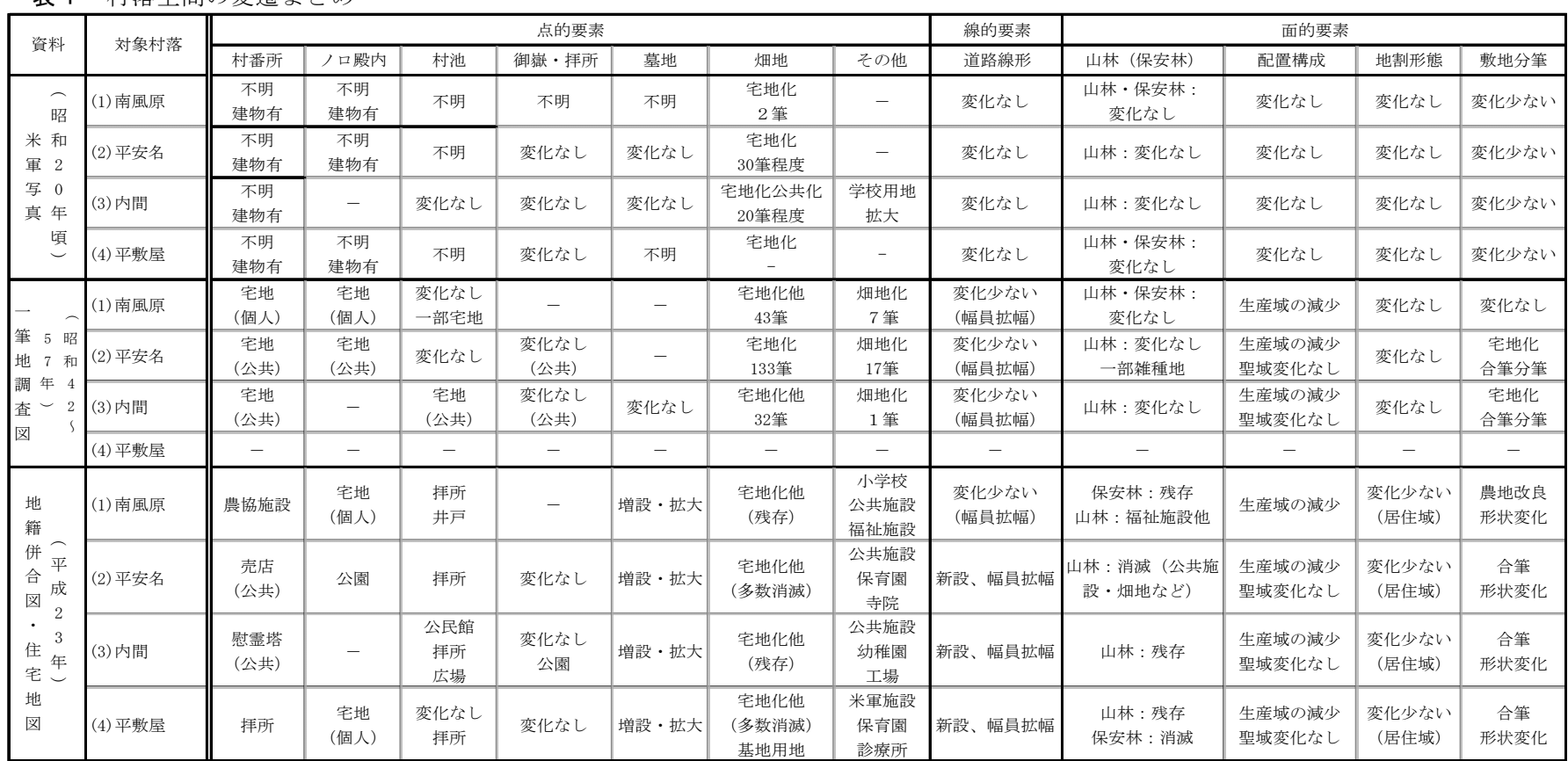


点的要素の道路は、幅員の拡幅が一部見られるが、新設や線形の 変化はほぼ見られず、また居住域内の道路沿いの水路もほぼ往時の 姿を残していた。居住域背後の丘陵地（腰当森）に分布する帯状の 山林は、地目や地筆形状にほぼ変化が見られず、村有の保安林とし

て機能していた。

面的要素の配置構成や井然型の地割形態にも変化が見えず、かつ

目立った敷地分筆も見られない。

平安名村の一筆地調査図は昭和 46 年作成である。村番所、ノ口 殿内は村有の宅地となっていた。ただし、村池や御猋には大きな変 化は見られない。村域内の畑地 133 筆が宅地に変化している一方で、 居住域内の宅地 17 筆が畑地に変化している。その他は南風原村と 同様に、線的要素、面的要素ともに大きな変化は認められないが、 宅地化による敷地の合筆や分筆は進んでいる。

内間村の一筆地調査図は昭和 57 年作成である。村番所及びそれ に隣接する大きな村池は村有の宅地に変化している。その他の村池 は残存しており、拝所も往時の位置を守っている。村域内の畑地は 32 筆が宅地に変化している一方で、居住域内の宅地 1 筆が畑地に変 化している。

なお、平敷屋村の一筆地調查図は現時点では確認できていない。

\section{（3）現在 (表 1 )}

地籍併合図と住宅地図によれば、南風原村の点的要素の村番所は 農協施設に変化し、ノ口殿内は一筆地調查図の当時と同様に個人所 有の宅地となっている。村池は、埋め立てられて洋所となっていた り、井戸として残存していたりする。村域内では、畑地が宅地や小 学校、その他公共施設に大きく変化している。なお、居住域四隅の 村獅子は西北端 1 箇所のみ残存している。

線的要素の道路は、特に居住域外において幅員の拡幅が見られる が、村域での道路新設や線形の変化はほぼ見られない。居住域内の 水路も暗渠化されながら残存しており、現在も使用されている。

面的要素としては、農地改良による畑地の地筆形状の大幅な変化 が見られる。また、大規模な公共施設が建設されて生産域の減少が 見られるが、居住域と生産域の大きな構成は変化しておらず、かつ ての村落の空間構成の大部分は現在まで残されている。居住域背後 の山林の地筆形状も残存しており、現在でも樹林帯が確認できる。 一方で、保安林の指定から外れていた山林が、大規模な福祎施設や 公園などとなって消滅している。

平安名村の点的要素として、村番所は字の売店に、ノ口殿内は児 童公園に、村池は拝所にそれぞれ変化している。一方で、御苝は大 きな変化はなく、現在まで残存している。また、線的要素となるが、 居住域の南側に接して幹線道路（県道 8 号）が新設されている。 面的要素として、村域内の山林の多くが畑地や公共施設、寺院と なるなど、土地利用の変化を見せている。村域内では、居住域北側 の畑地の大部分が宅地に変化している。近隣の他村落（与那城）の 村域まで居住域が著しく拡大し、生産域の多くが消滅するなど、面 的要素の構成は大きく変化した。一方で、復元図で示した居住域の 範囲においては、その地割形態がほぼ変化しておらず、明治期から の形態が残存している。

内間村の点的要素として、村番所は慰霊塔（広場）に、村池は公 民館や拝所に変化している。ただし、拝所や馬場、学校に大きな変 化は見られない。村域内の畑地は平安名村と同様に宅地や公共施設
などに大きく変化し、加えて村落の北側に幹線道路（県道 8 号）が 新設され、村落空間の構成に变化が見られるが、線的要素としての 居住域内の道路線型には大きな变化がない点も、平安名村と同様で ある。

一方で、面的要素については、平安名村と異なり、居住域の拡大 は比較的少なく、生産域にも大幅な減少は見られない。なお、居住 域内の地割形態は平安名村と同様に変化していない。

平敷屋村の点的要素として、村番所は拝所に、ノ口殿内は個人所 有の宅地に変化している。一方で、村池と御訔は大きな変化はなく、 現在も残存している。また間切番所は宅地に変化している。

線的要素として、居住域の北側に接して幹線道路（県道 8 号）が 新設されている。

面的要素として、村落内では居住域北側の畑地の大部分が宅地に 化し、海側の居住域から山林をはさんだ南側の畑地は、米軍施設 (ホ ワイトビーチ) の配置によって、広範にわたって完全に消滅してい る。その中で居住域南側の山林については、地筆形態がほぼ維持さ れており、現在でも樹林帯が確認できる。一方で海沿いの山林は、 烟地と共に基地施設によって完全に消滅している。

また、近隣の他村落（与那城 饒辺）まで居住域が拡大したこと による生産域消滅も発生しているため、面的要素の構成には大きな 変化が見られる。一方で、復元図で示した居住域の範囲における地 割形態は、明治期からほぼ変化していない。

\section{5.まとめ}

本研究ではまず、明治期（35・36 年）の村落空間の詳細な復元図 から、往事の村落空間の特徵を明らかにした。そして、近世期に村 落移動を経験した南風原村、内間村と、移動のなかった平安名村、 平敷屋村とを取り上げて比較した。このうち、村落が移動した南風 原村においては、居住域背後の腰当森の山林 (のちに保安林と加筆) が村落全体を取り囲む構造が確認された。これは、前稿で指摘した 八重山・石垣島の近世村落の空間的特徵「村抱護」にきわめて類似 した構造であり、沖縄本島の村落においても、風水思想に基づいた 地理的概念いわゆる「抱護」が存在した可能性を示唆できた。

加えて、南風原村、内間村の地割形態は井然型が優勢で、かつ、 その構造は共通して直線的であり、特に南風原村では、居住域四隅 の村獅子に見られる風水的な像徵物の配置や、道路一の水路併設と いった計画的村落の特徴が見られた。そして、村落移動などで「村 建て」を行う際、ある基点をよりどころとして村落の配置を行うと いう近世村落の計画手法の一端が明らかになった。れについては、 内間村が村建ての際に植えたとされるホウヤー木も同様に基点であ ったと考えられるが、その究明は今後の課題である。ただし、両村 においては、この地域の村落において一般的にみられる御嶽がみら れなかった。

一方、移動していない平安名村、平敷屋村は、村内に御获を持っ ている。居住域の地割形態については、村の主要な集約されている 範囲となる、居住域の中央部分では不井然型で、その街区構成には 田の字型が見られるが、居住域の端部に行くほじ井然型となり、そ の構成には横一列型が多くなる、という共通性が認められた。

また、いずれの対象村落においても、居住域の背後に丘陵地（腰 当森）が存在していたが、その位置は必ずしも居住域の北側ではな 
く、地形や立地特性によって多様な位置にあった。

そして本稿では、このように明治期の村落空間の特徴を示した上 で、明治期から現在までの村落空間の変遷を考察した。まず、対象 村落に共通して、明治期から昭和 20 年頃までは、空間構成に大き な変化がなかったことが明らかとなった。加えて、昭和 42〜57 年 までにかけては、道路の幅員拡幅が一部見られるものの、道路の新 設や線形の変化及び地割形態に目立った変化はなかった。一方で、 居住域の拡大、生産域の減少は顕著であった。また、村池や御猋・ 拝所には、大きな変化はなかった。このような傾向は、前稿で示し た石垣島の村落と共通している。

そして現在まででは、幹線道路の新設や、生産域の消滅と居住域 の著しい拡大など、村落構造の変化が見られた一方で、御嶽・拝所、 村池（扯所）は残存した。この点においても、石垣島の村落におけ る空間構造の変遷過程に極めて類似していることが指摘された。

一方で、1800 年代に設置されたとされる居住域内の灌溉用水路が 現在もなお残存して使用されている点や、対象村落に共通して山林 の著しい消滅が見られるなかで、村落の腰当森にある帯状の山林(後 に保安林に指定されたものを含む) に限ってはそのまま残存してい る点は、昭和 20 年頃にはすでに一部消滅が確認された前稿の平得・ 真栄里村の樹林帯の消滅過程とは異なる特徵と言える。加えて、平 敷屋村に見られるような、米軍基地の設置に伴う土地接収により広 範囲にわたって生産域と山林が消滅している点は、沖縄本島ならで はの条件によるものであり、石垣島の村落における空間構造の変遷 過程とは大きく異なる特徴と言える。

以上、本稿では明治期の資料をもとに検討を加え、明治期の村落 空間の復元図によってその様相を検討し、現在までの村落空間の変 遷を考察した。今後は、明治期の土地台帳までもが残された宮古島・ 多良間島の村落を分析する予定である。

なお、一筆地調查図及び米軍空中写真の収集では沖縄県立公文書 館の協力を得た。村落の空間構成の考察では琉球大学教授仲間勇栄 氏にご指導いただいた。ここに記して謝意を表したい。

本研究の一部は、文部科学省科学研究費補助金基盤研究(B) 研究 代表者：鎌田誠史「沖縄の固有文化が持つ環境観と空間形成技術か ら見る集住環境の構成原理に関する研究」課題番号 : 22360257、 文部科学省科学研究費補助金基盤研究(B) 研究代表者 : 浦山隆一 「沖縄の集落空間における伝統的人工林「抱護」の形態と機能に関 寸る研究」題番号：21360300、の成果に基づくものである。

\section{参考文献}

1）鎌田誠史・浦山隆一・齊木崇人：八重山・石坦島の近・現代における村落 空間の特徴と変遷に関する研究一村落空間構成の復元を通して その 1 一 日本建築学会計画系論文集 Vol77、No. 679、pp. 2073〜2079、2012.9

2) 金城善: 明治三十五・三十六年の村の分合配置区域字各について, 沖縄県 地域史協議会 2011 年度第二回研修会資料, 2011. 10

3）齊木崇人: 農村集落の地形的立地条件と空間構成に関する研究, 学位論文, 1986. 2

4）平凡社地方資料センター：沖縄県の地名，平凡社， 2002.12

5) 字誌編纂委員会 : 勝連町南風原字誌、南風原公民館、2000.10

6)「角川日本地名大辞典」編纂委員会: 角川日本地名大辞典 47 沖縄県, 角 川書店, p. 191， 1986.7

7）勝連町教育委員会 : 文化財解説案内板、1990.3

8）野原昌常 : 勝連村誌，勝連村役場，1966. 3
注

注1）本研究では、村落空間の復元図作成の根拠資料として明治期の地籍図 に依るところが大きいため、地籍図を入手できる 4 村落を研究対象と した。

注2）沖縄の土地整理事業は、明治 32 年から 36 年まで行われた。本稿の研 究対象地域一帯では事業は明治 $35 \cdot 36$ 年頃に本格化し, 同時期に初め て近代的な測量による地籍図面が整備された。本研究は、この原図を 活用することから，明治 $35 \cdot 36$ 年頃を対象とする。

注3）「抱護」とは特定の場所を風水害から保護する施設（地形・森林）を指 寸用語で、風水思想に基づく地形的概念を含み、蔡温などによって計 画的に木々が植えられた例も多い。立地条件の相違によって浜抱護、 村抱護、屋敷抱護といった種類がある。

注4）「村落空間の復元図」は、明治期の資料（地籍図）を使用し、明治 35 ・ 36 年における村落の地割、道路構成、地目を記載し、文献・伝承など の情報をもとに施設等を復元することで、往事の村落空間の可視的な 特徴を把握することを目指したものである。

注5）第二次世界大戦中、米軍は沖縄県の上陸前に B29 爆撃機等によって空 中写真による偵察活動をおこなっていた。そして撮影された航空写真 は現在、沖縄県立公文書館に保管されている。

注6）戦災によって壊滅的な被害を受けた沖縄県において、敷地境界を明確 にするため、米軍政下から 1970 年代にかけて現地調査によって作製さ れた調査図である。

注7）沖縄ならではの事情として, 第二次世界大戦前までの地図資料が大き く不足していることが挙げられる。本土の都市部などにおいては, 1880 （明治 13）年以降 2 万分の 1 迅速則図または仮製地形図，1910（明治 43）年以降 2 万 5 千分 1 地形図といった比較的大縮尺の地形図が整備 されているのに対して, 沖縄県地方では 5 万分の 1 地形図 (「那覇」 については 2 万 5 千分の 1 地形図あり）程度しか整備されてこなかっ た。その中で、本稿で基礎資料とした土地整理事業当時の地籍図は、 ほぼ実測図であり、明治期における地目（土地利用）展開やその面積 規模を正確に示すことが可能となる。ただし、こうした地籍図も，特 に沖縄本島では今帰仁村, 南城市 (旧大里村)、うるま市（旧勝連町） 程度しか残存していない。

注8）石垣市史編集委員会の『石垣市史』や崎浜靖：地籍資料を利用した歴 史空間の復原作業(1)宮古・東仲宗根添における土地整理法施行時の空 間構成 、南東文化 $22 、$ pp. 75 85、2000 があるが、いずれも村落空 間の分析は行われていない。

注9）「保安林」指定は土地整理事業後に行われたものである。本稿の対象地 域では，土地台帳が残存しておらずその指定時期を特定することがで きないため、復元図では凡例を、当初地目である「山林」で統一した。

注10）復元作業の基図とした明治期地籍図は、字ごとに描かれているため、 つなぎ合わせて 1 枚の村落全体図とする必要がある（図 2 ）（図 3 ）。 具体的な手順としてはまず、字ごとに描かれた地籍図を画像処理ソフ トで補正しながらつなぎ合わせてデジタル化した基図を作成する。次 に、同じ場所の現在の地籍併合図の上に基図を重㸚あわせて精細な照 合と整合を行い、基図を補正して整合性を持たせた。さらに、作成し た基図における地筆線をトレースし、ベース図を作成した。このよう な手順で作成されたベース図に明治期地籍図に記載された情報（井戸、 墓地、宅地、原野、烟地、御猴、保安林、池・沼等）を記載した上で、 文献・伝承による情報を加え、さらに現地調査で確認した内容を記載 して明治期の村落空間の復元図を作成した。

注11）一部、6 筆構成の街区が存在するが、地番に枝番が付与されているため、 のちの分筆によるものと考えられる。

注12）近世地方経済資料十巻に、享保十二年薩摩から貢米盛増の指令があっ たが、勝連間切南風原はその前年に敷替をしたばかりであることを理 由として盛増を免されたとある。

注13）首里王府の急ぎの文書を各間切に伝達することを「宿次」と呼び、各 間切には間切番所が設置されていた。この間切番所を結ぶ街道を「宿 道」と呼び、首里城から各方面に放射状に伸びていたとされる。

注14）球陽尚穆王三七年条に「乾隆五三年（1788）に移動」とある。

注15) 村落ごとに測量、作製年が異なる。

注16) 対象地域における昭和 20 年頃の米軍空中写真については、点・線・面 的要素の確認も可能であるが、各地目の筆数を正確に把握できる程の 精度ではないため、「筆程度」という表記とした。

（2013年 6 月10日原稿受理，2014年 2 月18日採用決定） 